\title{
Legislation and Lifelong Learning in Canada: Inconsistencies in Implementation
}

\section{SANDRA ROLLINGS-MAGNUSSON}

University of Alberta

\section{ABSTRACT}

Governments in Canada at both the federal and provincial levels indicate that they support the policy of enhancing education to increase the 'intellectual capital' of the Canadian workforce as they believe that this would in turn, improve the economy. The lifelong learning agenda is at the heart of this effort. However, it is argued in this article that a review of government policy as expressed in legislation reveals inconsistencies between rhetorical and actual statutory support for the lifelong learning agenda. The absence of the protection and sense of permanence that legislation provides to policy implementation means that any actions taken or programs created may be easily changed, ignored or eliminated with little public scrutiny or debate. Further, this absence establishes a lack of firm ongoing political commitment to achieving the learning agenda.

Acknowledgements: Financial support from SSHRC is gratefully acknowledged as are the comments and suggestions of the anonymous reviewers. 


\section{RÉSUMÉ}

Les instances gouvernementales canadiennes, tant au niveau fédéral que provincial, prônent une politique d'efforts en faveur de l'éducation, afin d'augmenter le «capital intellectuel» de la main-d'oeuvre canadienne et d'améliorer ainsi, espère-t-on, l'économie en général. La formation continue, au coeur d'une semblable initiative, est donc à l'ordre du jour. Toutefois, une étude de la politique gouvernementale telle qu'elle se manifeste dans la législation montre des décalages entre le soutien rhétorique au projet de formation continue et l'appui statutaire qui lui est concédé dans les faits. Le présent article avance que l'absence de protection et de sentiment de permanence qu'assurerait une législation se traduit par une situation où les mesures et les programmes mis en place sont susceptibles d'être facilement modifiés, ignorés, voire éliminés, avec un minimum d'investigation ou de débats publics. En outre, c'est un manquement qui traduit l'absence d'un véritable engagement politique à concrétiser le projet de formation continue.

\section{INTRODUCTION}

The Canadian labour market of the 1990s is unlike that of the 1970s. The importance of primary and secondary industries as sources of employment has been reduced, services enhanced, work processes reorganized and new tools and equipment incorporated into production (Banting, Beach \& Betcherman, 1995; Betcherman et al., 1994; Gera \& Mang, 1997; Heisz \& Cote, 1998; Osberg et al., 1995; Statistics Canada, $1992,1994)$. The lowering of trade barriers has exposed Canadian firms to additional competition, and as multinationals adjusted their productive activities to take advantage of low-cost centers of operation around the globe, the international labour market has become more integrated (Drache \& Gertler, 1993; OECD, 1997; Rutherford, 1996).

Associated with these changes, unemployment rates in Canada have increased throughout the 1970s, 1980s and much of the 1990s (Statistics Canada, 2000). Not until the late 1990s did the unemployment rate begin to decline. Much of the growth in employment resulted from management efforts to achieve workplace flexibility. These efforts included 
shifting toward part-time, temporary and other forms of contingent labour rather than employing workers on a full-time basis (Krahn, 1995; MacBride-King, 1997; Noreau, 1994). However, even with the unemployment rate down to $6.8 \%$ in $1999,1.1$ million people remained out of work (Statistics Canada, 2000, p. 20).

In attempting to resolve the personal, business and economic disruptions associated with unemployment, the ideology of lifelong learning, ${ }^{1}$ or at least those aspects of the ideology that promote improvement in the workplace and economy, has been promoted by a number of researchers. Betcherman, McMullen and Davidman (1998), Crompton (1996) as well as the Organization for Economic Cooperation and Development (OECD, 1997), for example, suggest that the higher the level of education attained by an individual, the better their chance of obtaining a higher-paying position. In addition, it is believed that the well-educated worker is less likely to become unemployed in the future. Butlin and Oderkirk (1997), Hall and Mirvis (1995), and the International Labour Office (ILO) (1998) indicate that job satisfaction and the chances of quickly becoming re-employed in the event of a job loss are also positively affected by the acquisition of new skills. A positive relationship also appears to exist between business success and learning as competitiveness, productivity and profits are all enhanced through the continuous upgrading of the skills of competent employees (Economic Council of Canada, 1992). In the past, Canadian economic growth has been based on the competitive advantage provided by abundant natural resources. However, recent reports suggest that "the collective skill of the people in our work force" (Premier's Council on Economic Renewal, 1994a, p. 2) or our national "intellectual capital" (Industry Canada, 1998, p. 1) is becoming the most important factor for the future. If these statements are correct, lifelong learning must be seen as a national priority (Ashton, Green \& Lowe, 1993). Further, it is believed that national economic viability, wealth creation, and social cohesion are tied to the success of the private sector (Prosperity Secretariat, 1991). Such a situation, in turn, would create a positive atmosphere, expand both corporate and individual tax bases and limit the number of claimants depending on government services, thereby 
improving the position of the nation along with individuals and businesses. With all of the advantages set out above that may, in theory, be gained from ensuring that education becomes a paramount consideration, it is not surprising that lifelong learning is so heavily promoted as a solution for economic and workplace concerns (see for example, Industry Canada, 1998; OECD, 1997, 1998; Premier's Council on Economic Renewal, 1994a, 1994b; Statistics Canada, 1997). Given the strength of this belief in learning one would expect to find many changes in state policies and funding initiatives to address the matter. Encouraging the expansion of education and training by both public and private entities would presumably be a top priority by this point. However, it is in attempting to establish that lifelong learning is being supported in fact rather than only rhetorically that inconsistencies in the responses of the federal and provincial governments begin to appear. A review of federal and provincial statutes provides little evidence of widespread or successful legislative efforts to incorporate lifelong learning, or even a limited aspect of lifelong learning, into practice for all Canadians.

\section{RESEARCH METHOD}

In determining the actions taken by the federal and provincial governments in promoting a formal lifelong learning agenda, all statutes that have an apparent direct or indirect relationship to, or effect on, the provision of education or training in Canada have been examined. In undertaking this research, efforts to identify relevant federal and provincial statutes were limited to legislation existing between 1980 and 1998. Statutes were located through a review of statutory indexes published by each legislative authority to provide information on all legislation enacted, amended or repealed during a legislative session. Any statutes that appeared to impact learning in Canada were then analyzed in greater detail.

The 1980-1998 time frame was chosen because legislative responses to the economic and workplace disruptions that were growing throughout the 1970 s began to appear in the early 1980 s. Statutory 
changes made prior to 1980 were also likely to appear in the statutory indexes reviewed and thus could be easily retrieved, if necessary. The 1998 cutoff was utilized as this was the most current statutory material available at the time of study for all of the jurisdictions involved.

In conducting this study, it should be noted that only government spending and statutes were considered. Programs and efforts undertaken by departments or local authorities without corresponding legislative amendments, while of value, were not considered for two reasons. Firstly, establishing programs without statutory revision suggests that despite the rhetoric supporting lifelong learning, actual political support for the concept may be lacking. Secondly, actions taken without formal statutory direction and protection are ephemeral and may just as easily be cancelled without notice, public scrutiny or debate in parliament or in a legislature. Political priorities change frequently and as such, it is important to note which, if any, policies are subject to the protection that legislation can provide against the whims of particular individuals, departments, or political parties as budgets and policy directions for primary, secondary and postsecondary schooling are determined.

\section{INCONSISTENCIES IN FEDERAL STATUTES}

The spending power of the federal government and its jurisdiction over programs relating to unemployment (The Constitution Act, 1940), give it a major role in setting policies appropriate to encouraging lifelong learning in Canada. These policies include exercising the spending power to fund educational institutions and student loans while also ensuring that training opportunities are made available for the unemployed. Most federal statutory initiatives in this field are based on these two aspects of jurisdiction but federal powers of taxation and over labour relations in a limited number of industries also play a role. However, in exercising these powers, inconsistencies arise.

\section{Employment Insurance Act (1996)}

The federally administered and funded systems of wage replacement and worker re-training that had been in place prior to 1996 under the 
Unemployment Insurance Act (1985) and the National Training Act (1985) were repealed and replaced by provisions in the Employment Insurance Act (1996). The stated purpose had been to provide a national program of occupational training "to better meet the need for skills created by a changing economy" by covering the costs of those adults who could increase their "earning and employment potential" through schooling (National Training Act, 1985, section 3). Under the Employment Insurance Act (1996, section 59) training became one of several active labour market programs paid for out of insurance premiums. Other programs included efforts to encourage employers to take on new workers, provide earning supplements for those taking new positions, helping the unemployed to start businesses and establishing work experience opportunities. Benefits would be lost for up to six weeks for those unemployed persons who refused to undertake the required courses, failed to attend and pass the courses, or were expelled, and as such the training incentive was quite real (sections 27-28).

The training function was presumably to be administered directly by the Canada Employment Insurance Commission. However, the combined effect of the Employment Insurance Act (1996) and the Department of Human Resources Development Act (1996) was such that after both acts were proclaimed, agreements could be implemented to transfer responsibility to the provinces. In fact, the Canada Employment Insurance Commission has altered the coordination of initiatives by delegating federal training functions to the provinces. The provinces administer training programs for those persons referred to them by the Commission with funding from employment insurance premiums being provided directly to the individual to purchase education or training locally (Hale, 1998). However, the training policy allows for the possibility of requiring the individual to repay a portion of the funding as the operating premise is that "better results are achieved when people choose and contribute financially" (Poisson, 1996).

While eliminating one level of bureaucracy from the process may make economic sense and provide greater provincial autonomy, one must question whether this disrupts the broader view of the national employment scene and coordination of training efforts. Administrators 
functioning at the provincial level would certainly have a stronger grasp of the local employment situation. Based upon this localized knowledge of job availability, appropriate training or educational courses could be recommended that would improve the opportunities for employment. However, with the changes that are occurring in the national workforce as a result of the transition toward a more service and information oriented economy, mobility and training for positions opening in other regions could be a necessity. Losses in one jurisdiction could be matched by gains in different fields in another jurisdiction. Without a coordinating body to ensure cross-matching of information, efficiency gains achieved by eliminating overlapping programs could be lost as ten different provincial bodies and numerous local offices attempt to place their own local perspectives on the value of particular training efforts. This could limit the viability of policies necessary to increase the 'intellectual capital' of the country as a whole as called for by those in the government who promote lifelong learning.

In addition, although the emphasis on training and other active policies matched well with the lifelong learning philosophy in the sense that they attempted to attack unemployment by increasing the human capital of those in need, the government's actions were inconsistent. Expenditures on training, increased as a percentage of spending out of insurance premiums, but actually declined in dollar terms. A number of factors contributed to this shift of the training burden. Funding from general tax revenues was decreased and more insurance funds were used to cover expenses related to training and other active labour market policies during the mid 1990s. At the same time, claims for income replacement were declining (Hale, 1998). In other words, despite the call for education and training to bolster Canada's economic potential, actions were taken that shifted the cost burden to individuals and employers through employment insurance premiums without increasing the financial commitment of the Federal government.

Given the government's concentration on eliminating deficit spending, this is not a totally unexpected outcome. However, statements made in federal promotional material in 1994 seem to highlight the position that rhetoric, rather than a more positive financial contribution, will be 
the extent of the federal response. The Department of Finance (1994, p. 41) indicated that although additional skills were needed by Canadians to take advantage of "new opportunities," the government's role would be limited to assisting people because "the primary responsibility to develop the nation's base of skills lies with Canadians themselves." This has since been confirmed by a senior member of Human Resources Development Canada who indicates that budget cutbacks mean that people must cover a larger portion of the cost of education and training while the government takes on a different role. The tasks of the federal government will involve assisting individuals, encouraging private sector training, generating information on employment availability and distributing data respecting the cost, quality and availability of training throughout the country are to be, rather than contributing to education funding to the same extent as in the past (Poisson, 1996).

\section{Department of Human Resources Development Act (1996)}

While the authority of the Canada Employment Insurance Commission is limited to dealing with the unemployed under the Employment Insurance Act (1996), its jurisdiction is widened by section 6 of the Department of Human Resources Development Act (1996). Effectively, the Commission has authority over all matters relating to human resource development "with the objective of enhancing employment, encouraging equality and promoting social security" under section 6 . As noted earlier, the involvement of provincial authorities is specifically encouraged and certain other responsibilities relating to benefits and training are imposed. As such, this statute allows for the centralized administration of information gathering, employment offices and employment insurance. If handled carefully, the Department has the potential to actively promote lifelong learning by dealing with those in need in a coordinated fashion, although delegating training administration to the provinces has reduced that potential to a degree.

Given these basic functions designed to enhance the future of hundreds of thousands of Canadians, it is somewhat ironic that the department was also given responsibility for administering benefits set out under the Labour Adjustment Benefits Act (1985). This Act had little to 
do with assisting beneficiaries to obtain employment. Rather, it acted as an advance retirement fund to provide relief, over and above that available through regular Unemployment Insurance. Only workers between 55 and 65 years of age who lost employment in industries that were "undergoing significant economic adjustment of a non-cyclical nature due to import competition or by reason of industrial restructuring" qualified for benefits. While new beneficiaries have not been added during the 1990 s, the statute remains on the books despite its philosophical opposition to the lifelong learning concept. Specifically, any beneficiaries who pursued retraining under the National Training Act (1985) lost their claim to adjustment benefits, a policy that would hamper the return of experienced individuals to the workforce.

\section{Canada Student Financial Assistance Act (1994)}

For those individuals who are outside of the labour force but able to take part in formal training, funding is available through the Canada Student Financial Assistance Act (1994). This statute replaced the Canada Student Loans Act (1985) with new rules that have increased the amount of available loans, eased repayment terms and reduced interest rates. However, loans were also placed under the direct control of lending institutions and three years later, the right to eliminate student debts through bankruptcy proceedings was made less available as an option for those unable to repay their loans (An Act to Amend the Bankruptcy and Insolvency Act, the Companies' Creditors Arrangement Act and the Income Tax Act, 1997). Under this revision, student loans obtained with either federal or provincial backing may no longer be eliminated through bankruptcy proceedings if the bankruptcy occurs while the individual is still a student or within two years of ceasing to be a student, unless a court orders the contrary. No such court order can be made unless it is clear that the student will be unable to pay back the loan despite his or her good faith effort to do so. This once again emphasizes the federal philosophy of assisting individuals, but expecting students to make their own choices and take responsibility for their own education. Income-based repayment is not available. If learners obtain a loan and choose training that prevents them from obtaining 
a position well enough remunerated to enable repayment, the ability to start over is less available than it was prior to 1997. This new system may thus actually limit individual choices of career in the long term as learners scramble for classes that offer access to better-paying, rather than preferred occupations.

As happened with training under the Employment Insurance Act (1996), provincial authority has also been expanded in the loan scenario. This federal statute authorizes the guarantee of loans made by lending institutions to students. Beyond that, provincial bodies administer the system, cover the designation of postsecondary institutions that loan recipients may attend, and set the maximum loan amounts by way of an agreed formula. While this federal funding, in combination with the sums put up by the provinces themselves, provides assistance to many people, those unable to afford even the reduced interest rates under these programs or who are unable to attend standard classes are ignored. As such, increasing student loans alone will not lead to achieving the goals of lifelong learning, particularly when other funding reductions and policies are inconsistent.

In particular, total public expenditures on education (by all levels of government) dropped on a per capita basis between 1994-1995 and 1998-1999. This reduced the ability to provide new services and encouraged fee increases at the postsecondary level. Public spending had increased for universities, colleges and trade vocational institutions between 1988-1989 and 1994-1995, but only the trade vocational category experienced a net increase above levels required to accommodate new entrants. Approved student loan amounts were increased as fees climbed, but at a slower rate than fee growth (Little, 1997).

Public spending on education in Canada is higher than the average among OECD countries (13.6\% of all government expenditures as compared to $12.7 \%$ ), but the proportion of public to private spending on education has shifted. Government funding of universities, for example, supported $74 \%$ of operating budgets in 1982-1983 but this dropped to $55 \%$ by $1998-1999$. As a result, fees doubled between 1988-1989 and 1998-1999, and enrollments have fluctuated. Trade vocational registrations for both full and part-time students declined between 1987-1988 
and 1995-1996. For colleges, registration for part-time students did not begin to drop off until 1992-1993, but full-time registrations have increased steadily. Entrance to part-time university programs collapsed after 1992-1993 and entrance on a full-time basis leveled off in 1991-1992 after growing at a high rate in the late 1980s and early $1990 \mathrm{~s}$ (Canadian Education Statistics Council, 2000, p. 53). Not all of this can blamed on or credited to changing fee structures; other economic factors, including the recession of the early 1990s, would also have had an impact. However, reducing per capita spending during a time period when enrollments were on the decline, or at least falling back from a historical pattern of more rapid increase, does not fit logically with a real intent to promote learning as a source of national progress.

\section{Income Tax Act (1985) and Canada Labour Code (1985)}

While the changes that have been made in the Federal statutes linked to education and training are a step toward the establishment of lifelong learning as a positive goal, one must also recognize that they do not portend success in the endeavor. As suggested by Poisson (1996), conflicting fiscal goals have lead to a partial withdrawal of federal funding to the education system in Canada. This withdrawal will reduce the influence that the federal government may once have possessed to direct the course of action to be followed in pursuing the matter. A portion of these funds may be said to have been replaced through a number of tax initiatives sponsored by the federal government. Credits provided to both full and part-time students to offset costs incurred while attending postsecondary institutions have increased, and the government now offers matching contributions ( $20 \%$ of private contributions to a limit of $\$ 400$ per year) to Registered Education Savings Plans (Income Tax Act, 1985). However, as with loans to students, this plan assists only those capable of making the initial investment. A similar argument may be made with respect to the federal "Lifelong Learning Plan." This policy change will allow the withdrawal of up to $\$ 10,000$ per year (to a limit of $\$ 20,000$ ) from Registered Retirement Saving Plans to cover qualifying education costs (Income Tax Act, 1985). A further initiative being brought forward as part of the February 28, 2000 federal budget also 
addresses the funding issue. This policy will amend the tax code to increase the portion of scholarship, grant or bursary income exempt from taxation to $\$ 3000$ from $\$ 500$, but one must be involved in an educational program to benefit.

Finally, one additional aspect of federal policy is worthy of note, particularly as no province has taken a similar stance. An amendment to the Canada Labour Code $(1985$, sections $209,209.3)$ provides that employers cannot refuse workers the opportunity to be trained or promoted only because they are, or intend to, take leave for maternity or paternity. Further, it is stated that these workers have the right to be notified of such training opportunities in writing.

Overall, advances made through the revision of the employment insurance system, the creation of new information resources, increasing the availability of loans and juggling tax policies do less than might otherwise have been expected to expand learning for those Canadians faced with serious barriers to training. This situation may, perhaps, be an expected outcome given that the provinces hold primary power and responsibility, if not the budgetary means, to enhance education. However, further progress is made dependent upon the actions, or lack thereof, of the individual provincial governments.

\section{INCONSISTENCIES IN PROVINCIAL STATUTES}

The ten provinces of Canada are granted authority over the regulation of employment and the conduct of education and training within their own borders by sections 92(13), 92 (16) and 93 of The Constitution Act, 1867 (formerly the British North America Act, 1867). As such, the policies of each province, as expressed in relevant legislation, must be examined to obtain the complete national picture of progress toward achieving the lifelong learning goal. The task is made more manageable, however, by the fact that, in many cases, laws dealing with issues that relate to learning are quite similar in terms of legislative intent, if not in terms of statute names, responsible departments and exact wording used to authorize action by these departments. As such, this analysis utilizes particular statutes to illustrate points of similarity between jurisdictions, 
but in situations where notable distinctions occur, greater detail of individual provincial approaches is provided.

As is the case with the federal government, a variety of provincial statutes could be employed in the effort to create a learning culture in Canada, but few new laws have been enacted since 1980 and few revisions have been made to then existing laws to stress that such a goal is to receive greater attention. Further, few changes altering established methods or historically developed bureaucratic processes and requirements have received statutory emphasis. While this does not identify actions taken at the department or local levels, the lack of statutory revision is troublesome.

In terms of the provincial legislation to be considered, the obvious starting point lies in the review of laws dealing with the administration of public education and training services. In addition to regulating the founding, financing, powers, staff qualifications and operation of publicly-operated institutions, including elementary and secondary schools, community colleges, technical institutes, universities and other providers of learning, each province also exerts control over privatelyowned vocational schools. Using Alberta as an example, this authority is exercised through statutes including the Colleges Act (1980) and the Private Vocational Schools Act (1980). As such, the provincial governments are in a position to influence all aspects of formal education services and thus to increase not only the number and variety of courses provided, but also their affordability and availability.

However, as noted when discussing federal student loans, budgetary restraint has limited spending in the education field, and, rather than reducing the cost of attendance to encourage greater participation, tuition fees have been rising. Accounting for inflation, real growth of university tuition fees in Canada was over $60 \%$ in the 1990 to 1995 period alone. At the same time, government grants per student have gone through a period of decline, resulting in universities increasing the portion of their operating budgets paid through fees from $14.6 \%$ in 1983 to $24.3 \%$ in 1995. Compounding this financial problem is the fact that, while real costs have risen, real incomes have not kept pace; the result is a rise in 
the proportion of average family income required to pay student fees from $3.1 \%$ in 1989 to $4.9 \%$ in 1994 (Little, 1997).

Little concludes that enrolment reductions in 1994 and 1995 are a sign that fees have become a deterrent to education. Only the poor economic conditions of the early 1990 s, which left young individuals with few choices but to attend school until the economy improved, held enrolments up despite the increase in costs. ${ }^{2}$ While Little's conclusion ignores the fact that there was a net increase in college program registrations throughout the 1990s (Statistics Canada, 1998), logic dictates that enrolments would have improved if costs had been lower and a broader range of choices available. Further, the Canadian Education Statistics Council (2000) has noted that the socio-economic gap in university attendance has been widening to the point that by 1994 , participation in university education by the highest socio-economic quartile is at $40 \%$ while the middle and lowest quartiles are at $25 \%$ and $18 \%$ respectively. Those in the lowest quartile are more likely to withdraw from secondary education without graduating as well. The impact of inconsistency between government statements respecting the value of learning, and government actions seems apparent.

As noted earlier, the federal government supports learning by guaranteeing loans to students, but it is the provinces that administer the system. While this policy aids many individuals, not everyone has the ability to utilize the loan system. For those unable to qualify for loans due to financial problems, who cannot adapt to standard schooling practices and scheduling, or who can attend only on a part-time basis (generally set at those enrolled in less than $60 \%$ of a full class load), provincial loan guarantees are not available. Loan policy is designed to support full-time students attending formal courses, at approved institutions, public or private. Alberta (Students Finance Act, 1980) and Quebec (An Act Respecting Financial Assistance For Students, 1990) do offer limited support in the form of small non-repayable bursaries to part-time students, and most jurisdictions have scholarships available. However, once again, these policies do little for those whose options are restricted by their circumstances. 
Despite the limitations of certain policies, some progress is being made toward creating a society that is more focussed on learning and the advantages (social as well as purely financial) that learning may have. Beyond formal schooling situations, the provinces are also in a position to exert control over forms of apprenticeship and other work training, including the training of professionals. Much of this jurisdiction, including defining the work that may only be performed by a member of a regulated trade, occupation or profession, is delegated to governing boards made up of specialists and practitioners in the particular industry. These boards also set standards to be followed in training, apprenticeship and practice, conduct examinations to determine qualifications, grant credit for prior work, training and certification in other jurisdictions, and deal with canceling member certification when necessary. As such, less authority is retained by the government in such fields to control the learning function but government does set the essential foundation for these actions and in most cases, controls the formal, non-work aspects of training that occur in colleges, vocational schools and universities. Given this, adjusting the availability of education and its costs may influence the participation of individuals in these fields. Further, by ensuring that governing statutes require the maintenance of current standards by all those working in particular fields as is done, for example, in Alberta's Apprenticeship and Industry Training Act (1991), or requiring updating classes as in Nova Scotia's Apprenticeship and Trades Qualification Act (1989), the lifelong learning agenda is supported. In fact, the government of British Columbia has specified lifelong learning and the promotion of apprenticeship, not simply its regulation, as express goals under its Industry Training and Apprenticeship Act (1997).

Legislation is also used to decrease the risks of dealing with learning providers outside of the public system. The government of Saskatchewan, for example, specifies the quality of instructors, materials and premises, requires proof of financial viability, bonds learning providers to protect students from loss, and regulates the sale of training to ensure honesty (The Private Vocational Schools Regulation Act, 1979-80; The Sale of Training Courses Act, 1978). Other actions taken by the various provinces that support the lifelong learning agenda 
include the establishment of distance education policies that enable learners to gain skills while remaining in convenient locations (see for example, Quebec's, An Act Respecting Private Education, 1992) and the funding of educational broadcasting (see for example, Nova Scotia's Educational Communications Agency Act, 1989; and British Columbia's Open Learning Agency Act, 1996) to provide information to people in their homes. Youth employment has also been promoted as a source of skill training (see for example, B.C. Benefits [Youth Works] Act, 1996; Ontario Youth Employment Act, 1990), and technical and scientific research financed (see for example, Alberta Science, Research and Technology Authority Act, 1998; Technical University of British Columbia Act, 1997).

It should be noted that several provinces have gone beyond rhetoric in putting forth a lifelong learning agenda. They have committed themselves to advance training and human resource development in statutory enactments. These provinces include Prince Edward Island, which has established an agency to coordinate access to training and work experience for those unable to obtain permanent employment (Employment Development Agency Act, 1993), and British Columbia, Saskatchewan and Quebec who have slightly more extensive policies in place.

Beginning with British Columbia, the Build B.C. Act (1996) specifies the promotion of "training and investment in people as a significant component of public sector investment activity" and establishes an initial budget of one hundred million dollars for training and the creation of work experience and employment generating projects (sections $2 \mathrm{~d}$ and 7).

In the case of Saskatchewan, the agency created under The Human Resources Development Act (1978) was established well before the call for lifelong learning as policy began. However, the agency is capable of pursuing actions to promote this agenda as it is authorized to go so far as to "initiate proceedings" against government departments and agencies that fail to follow recommendations to improve programs and services related to developing human resources (section $5 \mathrm{~d}$ ).

The province of Quebec is somewhat different in that it has endeavored to enhance the provision of training within its borders through the creation of a 'train or pay' levy and grant system. Employers subject to 
the legislation, including the government itself, are required to spend an amount equal to at least $1 \%$ of their total payroll on formal training programs through public or private schools, professional organizations, union accepted sources or internally if so authorized (An Act to Foster the Development of Manpower Training, 1995). Any amounts not spent on training must be paid into a fund utilized to establish training programs and as such, training throughout the province may be encouraged.

The province of Ontario appears to have taken a somewhat more expansive and aggressive approach to the lifelong learning agenda than is evident in most other jurisdictions, revamping legislation relating to both training and the education system in general. For example, the law establishing the Education Quality and Accountability Office in 1996 attempts to ascertain the "quality and effectiveness" of elementary and secondary education through mandatory achievement testing and recommendations for change (An Act to establish the Education Quality and Accountability Office and to Amend the Education Act with respect to the Assessment of Academic Achievement, 1996). Whether this actually improves education is unknown but, from a lifelong learning perspective, increasing the number of individuals with a solid early education is a positive goal. A quality education may reduce the number of adults who avoid future learning because of poor early experiences within the system. Further, under the 1993 statute, An Act to establish the Ontario Training and Adjustment Board (1993), the stated purpose is to improve "access to publicly-funded labour force development programs and services that will, in the context of the competitive Canadian and global economies and in the context of a fair and just society, lead to the enhancement of skill levels, productivity, quality, innovation and timeliness and the improvement of the lives of workers and potential workers" (section 1b). Goals also include creating common occupational training standards to improve skill portability, coordinating federal and provincial actions, linking all programs that promote training, employment and lifelong learning, eliminating systemic and other barriers to participation of disadvantaged and under-represented groups in these programs, designing and delivering programs based on the needs of employers, 
workers and potential workers and promoting sustainable levels of investment in labour force development (section 4).

The Ontario policy, if fully implemented and funded, would address virtually any barrier to learning. Whether ongoing funding, sufficient to achieve the goals, will be advanced in the face of almost universal budgetslashing throughout Canada is unknown. And while the statute refers to training for re-entry to the labour force, the law relates primarily to the employed, leaving those outside the labour market out of consideration. This is not unusual because individuals not covered by Employment Insurance funding and who are too long out of employment are dealt with under social assistance procedures in most provinces.

While all provinces expressly or implicitly (the provision of 'referral services' under Prince Edward Island's Welfare Assistance Act, 1988, for example) offer recipients of social assistance support for training that may help them to re-enter the job market and become independent, three provide for punishment in the event that the 'offer' of training is not pursued. Under Alberta's Social Development Act (1980, section 16), benefits may be reduced or eliminated for any recipient who "has refused or neglected to avail himself of appropriate training". Similar provisions exist in Manitoba under The Social Allowances Amendment and Consequential Amendments Act (1996) and in Ontario in accordance with the Ontario Works Act (1997, schedule A). The Ontario statute explains that its purpose is, among other goals, to promote "self reliance through employment" and be "accountable to the taxpayers" (section 1). Forcing claimants to take training is believed to accomplish these goals. This, of course, assumes that the training is in relevant disciplines, that positions will be available for the newly educated and that forced learning is legally permissible under the Canadian constitution. ${ }^{3}$

\section{CONCLUSION}

While the cumulative effect of all of the noted statutory policies is to assist a great many individuals, most have been in place for many years and are not directed at helping those who face major barriers to learning. Further, policies that do stand to benefit those most in need of help are 
designed to operate coercively rather than on a voluntary basis. Budget restraints add further complications, and the goal of ensuring that all individuals have the opportunity to benefit from lifelong learning is lost in the confusion of competing policy goals and jurisdictions. True progress cannot be expected until inconsistencies between actions and words are resolved, and until policy differences between provinces are rectified. The unemployed, older displaced workers, early school leavers, those employed by businesses that do not provide training, and those with other restrictions on their ability to participate in formal programs may be left behind in the absence of meaningful policy initiatives that move beyond rhetoric. Clearly, new policies must be developed that fully support the lifelong learning agenda and thereby create the opportunity for individuals, businesses and the overall economy to benefit from enhancement of the human capital and social benefits that this agenda offers.

For example, learning must once again be seen as having a social benefit and be funded accordingly by both the federal and provincial governments. Actions of changing social assistance policies to offer, rather than force, education and training to the least fortunate, in combination with fee reductions, making more funds available for part time studies and establishing income dependent repayment terms for students, would also increase accessibility. Tax deductions and delays do little for those most in need of assistance; increasing the level of available support would. Public financial support for informal training and implementation of a system to accredit such learning whether through courses, on-the-job training or personal experience, would also act to encourage the viability of the lifelong learning agenda.

The Quebec levy and grant system provides a useful guide that could be adopted in other jurisdictions to ensure training within industries at a reasonable level. Policies requiring a mandated expenditure by employers for retraining employees dismissed as a result of business reorganization or technological change could be added to relieve pressure from government budgets used in satisfying the needs of such displaced workers. The funds saved could be redirected to assist the many individuals who face difficulty in securing living expenses, let alone the costs of education. 
Perhaps most importantly, all policy adjustments must be properly funded and entrenched through legislative, rather than regulatory or departmental policy means. A coordinated series of provincial and federal statutes, or a single standard statute adopted in each province and in parliament, would not be immune to change in case of legitimate necessity. However, the public scrutiny under which such change would occur would lessen the chance of capricious alteration and allow for debate before amendment or elimination. Such a standardized statute could be based on the Ontario model discussed earlier. It would be advisable, however, for changes directed at lessening the emphasis on work-related learning as a criterion and enhancing the level of governmental financial support for all forms of learning. Recommending increased financing and a centralization of administration at this point verges on the reckless given the dominance of the neo-liberal philosophy of reducing spending, cutting regulation and encouraging the individual to take on more responsibility. However, funds do exist, and if learning is truly a necessity for the future, a more collective approach that maximizes opportunity and access for all is not a heretical suggestion.

\section{Notes}

1 Lifelong learning is explained by the $\operatorname{OECD}(1997$, p. 5) as being based on the concepts that "everyone should be able, motivated and actively encouraged to learn throughout life. This view of learning embraces individual and social development of all kinds and in all settings: formally, in schools, vocational, tertiary and adult education institutions; and non-formally, at home, at work and in the community." As such, if the application of the concept is to be limited to enhancing work related skills, knowledge and abilities, use of the term lifelong learning by government and related bodies may be inappropriate.

2 Bowlby and Jennings (1999) reached the opposite conclusion and suggested that youth school attendance was a result of their demand for education, not a result of being forced out of the labor market.

3 The issue of the constitutional propriety of coercive training schemes has been addressed by Drumbl (1994) who concludes that challenges may be 
legitimately raised against 'learnfare' as a breach of rights of recipients. He suggests that policies based on granting additional benefits to those who voluntarily undertake training are less subject to challenge than those that punish failure. Quebec, for example, offers additional funds to those taking training.

\section{References}

Ashton, D., Green, F., \& Lowe, G. (1993). The linkages between education and employment in Canada and the United Kingdom: A comparative analysis. Comparative Education, 29(2), 125-143.

Banting, K.G., Beach, C.M., \& Betcherman, G. (1995). Polarization and social policy reform: Evidence and issues. In K. Banting \& C. Beach (Eds.), Labour market polarization and social policy reform, (pp. 1-20). Kingston, ON: Queen's University, School of Policy Studies.

Becker, G.S. (1975). Human capital: A theoretical and empirical analysis, with special reference to education. New York, NY: National Bureau of Economic Research.

Betcherman, G., McMullen, K. Leckie, N., \& Caron, C. (1994). The Canadian workplace in transition. Kingston, ON: IRC Press.

Betcherman, G., McMullen, K., \& Davidman, K. (1998). Training for the new economy: A synthesis report. Ottawa, ON: CPRN.

Bowlby, G., \& Jennings, P. (1999). Youth employment: A lesson on its decline. Education Quarterly Review, 5(3), 36-42.

Butlin, G., \& Oderkirk, J. (1997). Educational attainment - A key to autonomy and authority in the workplace. Education Quarterly Review, 4(1), $32-52$.

Canadian Education Statistics Council. (2000). Education Indicators in Canada: Report of the Pan-Canadian education indicators program 1999. Ottawa, ON: Council of Ministers of Education.

Crompton, S. (1996). The marginally literate workforce. Perspectives on Labour and Income, 8(2), 14-21.

Department of Finance. (1994). Agenda: Jobs and growth - A new framework for economic policy. Ottawa, ON: Department of Finance.

Drache, D., \& Gertler, M. (1993). The world economy and the nation-state: The new international order. In D. Drache \& M. Gertler (Eds.), The new era of global competition: State policy and market power, (pp. 3-25). Montreal, QC: McGill-Queen's University Press. 
Drumbl, M. (1994). Exploring the constitutional limits to workfare and learnfare. Journal of Law and Social Policy, 10(Fall), 107-154.

Economic Council of Canada. (1992). A lot to learn: Education and training in Canada. Ottawa, ON: Minister of Supply and Services.

Gera, S., \& Mang, K. (1997). The knowledge-based economy: Shifts in industrial output. Working Paper. Ottawa, ON: Industry Canada.

Hale, G.E. (1998). Reforming employment insurance: Transcending the politics of the status quo. Canadian Public Policy, 24(4), 429-451.

Hall, D.T., \& Mirvis, P.H. (1995). Careers as lifelong learning. In A. Howard (Ed.), The changing nature of work, (pp. 323-361). San Francisco, CA: Jossey-Bass Publishers.

Heisz, A., \& Cote, S. (1998). Job stability. Perspectives on Labour and Income, 10(4), 24-29.

Industry Canada. (1998). Education and training Services, Part IOverview and prospects. Ottawa, ON: Industry Canada.

International Labour Office. (1998). World employment report 1998-99. Geneva: ILO.

Krahn, H. (1995). Non-standard work on the rise. Perspectives on Labour and Income, 7(4), 35-42.

Little, D. (1997). Financing universities: Why are students paying more? Education Quarterly Review, 4(2), 10-26.

Livingstone, D.W. (1998). The education-jobs gap: Underemployment or economic democracy. Boulder, CO: Westview Press.

Macbride-King, J.L. (1997). Contingent work: Lesson from individuals and organizations. Ottawa, ON: The Conference Board of Canada.

Noreau, N. (1994). Involuntary part-timers. Perspectives on Labour and Income, 6(3), 25-30.

OECD. (1997). Labour market policies: New challenges. Theme 3: Lifelong learning to maintain employability. Paris: OECD.

OECD. (1998). Education policy analysis. Paris: OECD.

Osberg, L., Wien, F., \& Grude, J. (1995). Vanishing jobs: Canada's changing workplaces. Toronto, ON: James Lorimar \& Company.

Poisson, Y. (1996). The role of governments in the development of human resources training for employability: The view from Canada. Canada-United States Law Journal, 22, 45-55.

Premier's Council on Economic Renewal. (1994a). Lifelong learning and the economy. Toronto, ON: Premier's Council. 
Premier's Council on Economic Renewal. (1994b). Lifelong learning and the economy: Summary report. Toronto, ON: Premier's Council.

Prosperity Secretariat. (1991). Prosperity through competitiveness. Ottawa, ON: Minister of Supply and Services.

Revised Statutes of Alberta. (1980). Colleges act. Chapter C-18.

Revised Statutes of Alberta. (1980). Private vocational schools act. Chapter P-17.

Revised Statutes of Alberta. (1980). Social development act. Chapter S-16.

Revised Statutes of Alberta. (1980). Students finance act. Chapter S-24.

Revised Statutes of British Columbia. (1996). B.C. benefits (Youth Works) act. Chapter 28.

Revised Statutes of British Columbia. (1996). Build B.C. act. Chapter 40.

Revised Statutes of British Columbia. (1996). Open learning agency act. Chapter 341 .

Revised Statutes of Canada. (1985). Canada labour code. Chapter 9 (1st Supplement).

Revised Statutes of Canada. (1985). Canada student loans act. Chapter S-17.

Revised Statutes of Canada. (1985). Income tax act. Chapter 1 (5th Supplement).

Revised Statutes of Canada. (1985). National training act. Chapter N-19.

Revised Statutes of Canada. (1985). Unemployment insurance act. Chapter U-1.

Revised Statutes of Nova Scotia. (1989). Apprenticeship and trades qualifications act. Chapter 17.

Revised Statutes of Nova Scotia. (1989). Educational communications agency act. Chapter 139.

Revised Statutes of Prince Edward Island. (1988). Welfare assistance act. Chapter W-3.

Revised Statutes of Saskatchewan. (1978). The human resources development act. Chapter H-15.

Revised Statutes of Saskatchewan. (1978). The sale of training courses act. Chapter S-3.

Rutherford, T. (1996). Socio-spatial restructuring of Canadian labour markets. In J.N.H. Britton (Ed.), Canada and the global economy: The geography of structural and technological change, (pp. 407-432). Montreal, QC: McGill-Queen's University Press.

Statistics Canada. (1992). Labour force annual averages, 1991. Ottawa, ON: Minister of Industry, Science and Technology. 
Statistics Canada. (1994). Labour force annual averages, 1993. Ottawa, ON: Minister of Industry, Science and Technology.

Statistics Canada. (1997). Adult education and training in Canada: Report of the 1994 adult education and training survey. Ottawa, ON: Minister of Public Works and Government Services Canada.

Statistics Canada. (1998). Education in Canada, 1997. Ottawa, ON: Minister of Industry.

Statistics Canada. (2000). Labour force update: An overview of the 1999 labour market. Ottawa, ON: Minister of Industry.

The Constitution Act. (1867). (formerly the British North America Act). United Kingdom. 30-31 Victoria. Chapter 3.

The Constitution Act. (1940). United Kingdom. 3-4 George VI. Chapter 36.

Statutes of Alberta. (1991). Apprenticeship and industry training act. Chapter A-42.3.

Statutes of Alberta. (1998). Alberta science, research and technology authority act. Chapter A-37.3.

Statutes of British Columbia. (1997). Industry training and apprenticeship act. Chapter 50.

Statutes of British Columbia. (1997). Technical University of British Columbia act. Chapter 54.

Statutes of Canada. (1985). Labour adjustment benefits act. Chapter L-1.

Statutes of Canada. (1994). Canada student financial assistance act. 42-43 Elizabeth II. Chapter 28.

Statutes of Canada. (1996). Department of human resources development act. 45 Elizabeth II. Chapter 11.

Statutes of Canada. (1996). Employment insurance act. 45 Elizabeth II, Chapter 23.

Statutes of Canada. (1997). An act to amend the bankruptcy and insolvency act, the companies' creditors arrangement act and the income tax act. 45-46 Elizabeth II. Chapter 12.

Statutes of Manitoba. (1996). The social allowances amendment and consequential amendments act. Chapter 41.

Statutes of Ontario. (1990). Ontario youth employment act. Chapter O.41.

Statutes of Ontario. (1993). An act to establish the Ontario Training and Adjustment Board. Chapter 9.

Statutes of Ontario. (1996). An act to establish the education quality and accountability office and to amend the education act with respect to the assessment of academic achievement. Chapter 11. 
Statutes of Ontario. (1997). Ontario works act. Chapter 25.

Statutes of Prince Edward Island. (1993). Employment development agency act. Chapter 5 .

Statues of Quebec. (1990). An act respecting financial assistance for students. Chapter 11.

Statutes of Quebec. (1992). An act respecting private education. Chapter 68.

Statutes of Quebec. (1995). An act to foster the development of manpower training. Chapter 43.

Statutes of Saskatchewan. (1980). The private vocational schools regulation act of Saskatchewan. Chapter P-26.1. 